\title{
Effects of applied cadmium on its accumulation, dry matter production and net photosynthesis in okra and amelioration of cadmium toxicity through lime application
}

\section{Authors Info \\ S. Raychaudhuri*, M. Raychaudhuri, S.K. Rautaray and S.R. Chowdhury \\ ICAR - Indian Institute of Water Management, Chandrasekharpur, Bhubaneswar, Odisha - 751 023, India}

*Corresponding Author Email : sachidulalraychaudhuri@yahoo.in

\section{Edited by \\ Dr. R. B. Raizada}

Reviewed by Dr. Anbunani Sadasivam Dr. Praveen Prakash

\section{Abstract}

Aim: Vegetables grown in cadmium contaminated soils accumulate cadmium in their tissues and are risky for consumption. The aim of the study was to get an insight into the effect of different levels of cadmium in soil, on accumulation in different plant parts of okra and its effect on overall growth, biomass production and photosynthesis rate so that suitable management option is explored to produce safe vegetable in cadmium contaminated soils.

Methodology: The study was conducted in replicated pots with three soil pH $(5.46,6.54$ and 7.45$)$ attained through addition of $\mathrm{CaCO}_{3}$ as main treatment and four $\mathrm{Cd}$ levels viz., $0,3,6$ and $9 \mathrm{mg} \mathrm{kg}^{-1}$ of soil as subtreatment. Okra (Abelmoschus esculentus) was taken as the test crop. The experiment was conducted in a nethouse.

Results: The Cd concentrations were minimum in fruits $(0.54,0.31$ and $0.14 \mathrm{mg} \mathrm{kg}^{-1}$ ) and higher in leaves at acidic $\mathrm{pH}$ (5.5), while in soil limed to slightly acidic (6.5) and alkaline $\mathrm{pH}(7.5)$ roots retained maximum $\mathrm{Cd}$ among plant parts. Net photosynthesis and biomass production decreased significantly with higher $\mathrm{Cd}$ doses at acidic $\mathrm{pH}$ (5.5). The rate of decline in net photosynthesis was lesser at higher soil $\mathrm{pH}$. The transfer factors decreased with increase in soil $\mathrm{pH}$. The DTPA extractable soil $\mathrm{Cd}$ decreased from 8.5 to $2 \%$ when soil $\mathrm{pH}$ increased rendering the $\mathrm{Cd}$ less available for plant uptake.

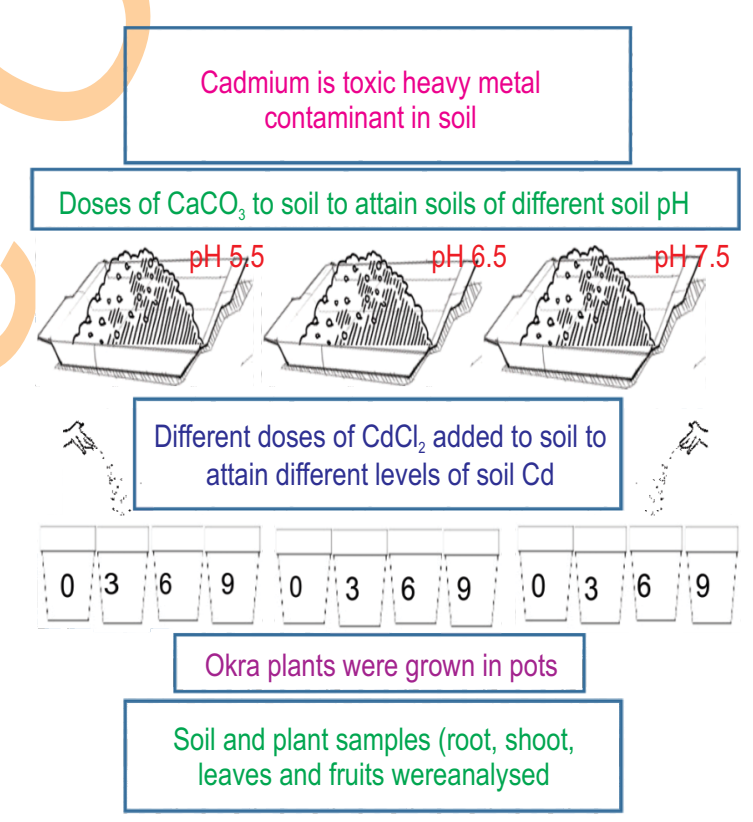

Interpretation: Liming can be an effective ameliorative measure to mitigate $\mathrm{Cd}$ toxicity in acidic soils and can ensure safe consumption. Lowest accumulation of cadmium in fruit part suggests okra to be a potential vegetable crop for $\mathrm{Cd}$ polluted soils.

Key words: Metal contaminant, Net photosynthesis, Soil pH, Transfer factor, Translocation factor

How to cite : Raychaudhuri, S., M. Raychaudhuri, S.K. Rautaray and S.R. Chowdhury : Effects of applied cadmium on its accumulation, dry matter production and net photosynthesis in okra and amelioration of cadmium toxicity through lime application. J. Environ. Biol., 40, 143-150 (2019). 


\section{Introduction}

Cadmium is known as a highly toxic element because of its toxicity and high mobility from soil to plants and further down the food chain (Vig et al., 2003). It is a natural contaminant of zinc ores and widely distributed in the environment due to anthropogenic activities. The major uses are in $\mathrm{Ni}-\mathrm{Cd}$ batteries, pigments, stabilisers, cadmium alloys and electronic compounds such as cadmium telluride ( $\mathrm{CdTe})$. The major products where it is present as an impurity are non-ferrous metals (zinc, lead and copper), iron and steel, fossil fuels (coal, oil, gas, peat and wood), cement and phosphate fertilizers. In agricultural soils, $\mathrm{Cd}$ contaminants are found in the parent rock of fertilizers and in sewage sludges (Chen et al., 2009).

In large part of peri-urban India a variety of vegetable crops are irrigated with urban wastewater (mostly untreated) supporting the livelihoods of the households of millions of farmers. The wastewater irrigated area in India was reported 72000 ha in 90s (Strauss and Bluementhul, 1990) but at present the area is likely to be much higher. There is an increasing risk of public exposure to heavy metals because of the consumption of food grown with sewage water (Balkhair and Ashraf, 2016). More than $10 \%$ of the world's population including India consume wastewater irrigated foods (WHO, 2006) with health risk potential. Among the heavy metals, $\mathrm{Cd}$ is one of the major pollutant metals, found in sewage irrigated vegetables such as brinjal, amaranthus, spinach, coriander and green chillies (Chandran et al., 2012, Usha Rani et al., 2014). Long-term application of treated sewage water results in significant build-up of total and DTPA extractable Cd (Ghosh et al., 2012). About 98\% of the ingested cadmium comes from terrestrial foods, and only $1 \%$ comes from aquatic foods such as fish and shellfish, and $1 \%$ arises from cadmium in drinking water (Van Assche, 1998).

Okra (Abelmoschus esculentus ( $\mathrm{L}$ ) Moench) is a popular vegetable in wastewater irrigated peri-urban areas. The crop is widely cultivated throughout the year in the tropic. India produce 5784 thousand tones okra and the productivity is $11.1 \mathrm{tha}^{-1}$ (Indian Horticulture Database, 2011). It is a good source of carbohydrates, protein, dietary fiber, calcium, magnesium, potassium and vitamins A and C (Mabberley, 1997). Very little is known about the effect of soil cadmium on its accumulation in different parts of okra plant and resultant effect on its metabolic activities.

This paper deals with the impact of graded doses of cadmium at different soil pH on overall growth, biomass, cadmium accumulation in different plant parts and photosynthesis rate of okra. The objective was to find whether changing the soil pH through lime can reduce the transfer of $\mathrm{Cd}$ from soil to okra plants so that liming can be a suitable measure to produce safer vegetables in cadmium polluted soil or with use of wastewater having cadmium.

\section{Materials and Methods}

The soil sample to be used in the experiment was collected in bulk from 0 - $0.2 \mathrm{~m}$ depth from the Experimental research farm at Deras, Mendhasal, Odisha, India. The soil sample was processed in the laboratory. The physico-chemical characteristics of the experimental soil were estimated as per the standard methods (Baruah and Barthakur, 1997). The $\mathrm{pH}(1: 2.5)$ was 5.5 having sandy clay loam in texture. The moisture holding capacity as estimated by Keen Raczkowski box method was $27 \%$, organic carbon was $5.6 \mathrm{~g} \mathrm{~kg}^{-1}$, permanganate oxidisable $\mathrm{N}$ was $195 \mathrm{~kg} \mathrm{ha}^{-1}$, Bray's P was $48 \mathrm{~kg} \mathrm{ha}^{-1}$ and ammonium acetate extractable $\mathrm{K}$ was $312 \mathrm{~kg} \mathrm{ha}^{-1}$. Total $\mathrm{Cd}$ content as estimated (Edgell, 1988) was $2.4 \mathrm{mg} \mathrm{kg}^{-1}$ and lime requirement as estimated (Brown and Cisco, 1984) was $9.0 \mathrm{t} \mathrm{CaCO}_{3} \mathrm{ha}^{-1}$. The collected soil was ground and passed through a 4-mm sieve, and was then used for the preparation of pot culture experiment. The bulk soil was divided into three parts. Three doses of powdered $\mathrm{CaCO}_{3}$ at the rate of $0,2.5$ and $5 \mathrm{~g}$ per $\mathrm{kg}$ soil were added and mixed uniformly to attain predetermined $\mathrm{pH}$ values of $5.5,6.5$ and 7.5 , respectively. The exact soil pH attained were $5.46,6.54$ and 7.45 . The soil of each $\mathrm{CaCO}_{3}\left(0,2.5\right.$ and $5 \mathrm{~g} \mathrm{~kg}^{-1}$ soil $)$ dose was divided into 4 portions and were uniformly mixed with $\mathrm{CdCl}_{2}$ solutions for a series of Cd levels viz $0,3,6$ and $9 \mathrm{mg} \mathrm{kg}^{-1}$ of soil at three levels of soil $\mathrm{pH}$. The cadmium doses were chosen considering the commonly encountered Cd levels in soil (Vinu Radha et al., 2014). That gave 12 number of treatment combinations.

The experiment was designed under factorial RBD with three pH levels of 5.5 (acidic), 6.5 (slightly acidic) and 7.5 (slightly alkaline) as main treatment and four $\mathrm{Cd}$ levels viz., 0, 3, 6 and 9 $\mathrm{mg} \mathrm{kg}^{-1}$ of soil as sub-treatments with three replications. Okra (Abelmoschus esculentus) was taken as the test crop. The experiment was carried out (Date of sowing $30^{\text {th }}$ September 2014) in the net house situated at ICAR - Indian Institute of Water Management, Bhubaneswar campus and watered daily in the evening.

The net rate of photosynthesis $(\mathrm{Pn})$ was monitored on the third fully expanded leaf from top of each plant on $30^{\text {th }}$ and $60^{\text {th }}$ days after sowing, using Infrared Gas Analyzer (IRGA) portable photosynthesis system (CHZA 2, PP system, Inc. USA). All the measurements were made between 8:30 and 10:30 a.m. Precautions were taken so that there should not have any moisture or dust on the leaf before inserting.

Soil and plant analyses: The plants were uprooted carefully at 90 days along with some soil, gently tapped to remove adhered soils with roots followed by washing under gentle running tap water followed by distilled water. The root length, shoot length and fresh biomass yield was recorded. To determine dry matter accumulation and $\mathrm{Cd}$ partitioning, harvested plants were separated into roots, stems, leaves and fruits (if any, as it was collected time to time) and their dry matter weight was 
determined after drying at $60^{\circ} \mathrm{C}$ to constant weight. Fruits reaching marketable sizes were harvested at four days interval till plants matured. At each time of harvesting, the harvests were counted and weighed followed by drying in oven at $60^{\circ} \mathrm{C}$ to constant weight. The total dry cumulative fruit weights per plant were calculated for fruit biomass. The total dry weight of stem, roots, leaves and fruits is referred as biomass. Leaf, stem, root and fruit samples were grinded separately, and $0.5 \mathrm{~g}$ samples were digested with triacid mixture $\left(\mathrm{HNO}_{3}, \mathrm{H}_{2} \mathrm{SO}_{4}\right.$, and $\mathrm{HClO}_{4}$ in 10:1:4 ratio) in a digestion chamber (Allen et al., 1986). Digested soil and crop samples were filtered through Whatman no. 42 filter paper, and the filtrates were diluted to $50 \mathrm{ml}$ with double distilled water.

The $\mathrm{Cd}$ concentration of the plant digest was analyzed using Atomic Absorption Spectrophotometer (Varian, Model No SpectraAA220).

The soil samples from each pots were collected after harvest (90 days after sowing) and processed for $\mathrm{Cd}$ analyses. The total soil $\mathrm{Cd}$ was determined from the digested soil samples (Edgel, 1988). Available Cd was determined by diethylenetriaminepentaacetic acid method, a non-equilibrium extraction developed by Lindsay and Novell (1978).

Cadmium concentration in the extracts of soils and plants were calculated on the basis of dry weight. The transfer factor (TF) of the plant parts were calculated as follows:

$$
\mathrm{TF}_{\text {part }}=\mathrm{C}_{\text {Plant parts }} / \mathrm{C}_{\text {Soil }}
$$

Cd translocation from one plant part to other part e.g. root to stem $\left(T L_{\text {stem-Root }}\right)$, stem to leaves $\left(T L_{\text {Leaves-Stem }}\right)$, leaves to fruit $\left(T L_{\text {Fruit-Leaves }}\right)$ was measured by Translocation Factor (TL) (Rezvani and Zaefarian, 2011).

Statistical analyses were performed using SAS (SAS, 2008) for analysis of variance applicable to factorial RBD. LSDs were conducted at $1 \%$ level of probability where significance was tested by F-test.

\section{Results and Discussion}

The decreasing trend in height with increasing $\mathrm{Cd}$ doses was observed and the trend declined with increased soil $\mathrm{pH}$. Both the $\mathrm{pH}$ and $\mathrm{Cd}$ doses had significant effect on plant height (Fig. 1). The plants attained maximum height at $\mathrm{pH}$ 6.5. In this study, cadmium doses or soil pH had no effect on root length, number of fruits per plant (not shown). Soil pH also had no effect on total biomass per plant (Table 1), though the increased $\mathrm{Cd}$ doses decreased the total biomass per plant. The decline in biomass yield over control $\left(0 \mathrm{mg} \mathrm{kg}^{-1} \mathrm{Cd}\right)$ was lesser in slightly acidic $(\mathrm{pH}$ $6.5)$ and slightly alkaline $(\mathrm{pH} 7.5)$ soil than that in acidic soil $\mathrm{pH}$. Fruit yield was not significant with cadmium doses and soil $\mathrm{pH}$. However, fruit yields showed decreasing trend with increased $\mathrm{Cd}$

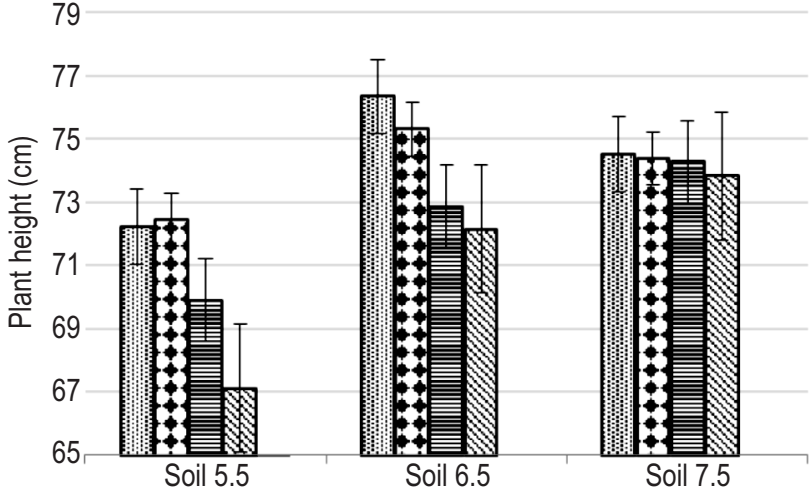

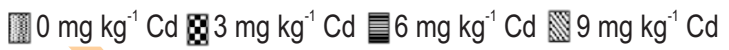

$\mathrm{CD}$ at $5 \% \quad \mathrm{pH} \quad \mathrm{Cd} \quad \mathrm{pH} \times \mathrm{Cd}$ $\begin{array}{lll}1.08 & 0.85 & 1.73\end{array}$

Fig. 1 : Effect of cadmium at different soil pH on plant height $(\mathrm{cm})$ of okra.

doses and was reverse with increasing soil pH (Table 1). Inhibition of growth and biomass production of plants exposed to $\mathrm{Cd}$ stress has been reported in several studies (Gu et al., 2007; Pilipovic et al., 2005). Most of the reported studies were conducted with much higher soil Cd levels $\left(15-200 \mathrm{mg} \mathrm{kg}^{-1} \mathrm{Cd}\right)$. The present investigation was in the range of 0 to $9 \mathrm{mg} \mathrm{Cd}$ level to simulate the commonly encountered levels of $\mathrm{Cd}$ in wastewater irrigated $(0.1$ to $2.23 \mathrm{mg} \mathrm{kg}^{-1}$ ) or disposed soils ( 7.65 to 8.2 ) (Vinu Radha et al., 2014). Probably, that is why the $C d$ stress was not manifested with altered root length, number of fruits or leaves under the range of applied $\mathrm{Cd}$ in this study. However, the effects of $\mathrm{Cd}$ on growth parameters like height and fruit weight are more pronounced at acidic soil $\mathrm{pH}$ in this study.

The apportionment of $\mathrm{Cd}$ to different plant parts changed with soil pH. In acidic soil (pH 5.5), cadmium concentration was found maximum in leaves followed by stem, root and fruits (Fig. 2). The passive influx of $\mathrm{Cd}$ through the root membrane channels permeable to some other divalent cations might have resulted in the increased $\mathrm{Cd}$ concentration in plant shoot (Stritsis and Claassen, 2013). At higher soil pH (6.5 and 7.5), the apportionment of $\mathrm{Cd}$ to plants parts was changed. It was higher in roots than leaves. However, the concentration of $\mathrm{Cd}$ in fruits remained minimum among all plant parts (Fig. 2). The maximum $\mathrm{Cd}$ in fruit ( $\left.1.02 \mathrm{mg} \mathrm{kg}^{-1}\right)$ was found in acidic soil $\mathrm{pH}$ with $9 \mathrm{mg} \mathrm{kg}^{-1}$ $\mathrm{Cd}$ application which was reduced to 0.58 and $0.22 \mathrm{mg} \mathrm{kg}^{-1}$ at slightly acidic (6.5) and alkaline (7.5) soil, respectively with the same level of applied $\mathrm{Cd}$. The concentrations of $\mathrm{Cd}$ in fruit were within the Indian permissible limits of $1.5 \mathrm{mg} \mathrm{kg}^{-1}$ (Singh et al., 2010) at all levels of applied Cd. However, the concentrations exceeded the WHO/FAO (2007) limit of $0.2 \mathrm{mg} \mathrm{kg}^{-1}$ even at $3 \mathrm{mg}$ $\mathrm{kg}^{-1} \mathrm{Cd}$ application in acidic soil ( $\left.\mathrm{pH} 5.5\right)$. When limed to slightly acidic condition (6.5) it was exceeded at $6 \mathrm{mg} \mathrm{kg}^{-1} \mathrm{Cd}$ application. Whereas, the $\mathrm{Cd}$ in fruit did not exceed the limit (WHO/FAO, 
Table 1: Effect of cadmium at different soil $\mathrm{pH}$ on total biomass and fruit $(\mathrm{g})$ of okra per plant

\begin{tabular}{|c|c|c|c|c|c|c|c|c|c|c|}
\hline \multirow[b]{3}{*}{ SoilpH } & \multicolumn{10}{|c|}{ Level of cadmium doses $\left(\mathrm{mg} \mathrm{kg}^{-1}\right)$ in soil } \\
\hline & \multirow[b]{2}{*}{ Biomass } & 0 & \multicolumn{2}{|r|}{3} & \multicolumn{2}{|r|}{6} & \multicolumn{2}{|r|}{9} & \multicolumn{2}{|c|}{ Mean } \\
\hline & & $\begin{array}{l}\text { Fruit } \\
\text { weight }\end{array}$ & Biomass & $\begin{array}{l}\text { Fruit } \\
\text { weight }\end{array}$ & Biomass & $\begin{array}{l}\text { Fruit } \\
\text { weight }\end{array}$ & Biomass & $\begin{array}{l}\text { Fruit } \\
\text { weight }\end{array}$ & Biomass & $\begin{array}{l}\text { Fruit } \\
\text { weight }\end{array}$ \\
\hline 5.5 & 38.2 & 14.4 & 39.0 & 14.6 & 36.7 & 13.3 & 35.6 & 12.8 & 37.4 & 13.8 \\
\hline 6.5 & 39.8 & 14.2 & 39.6 & 14.5 & 37.2 & 13.4 & 36.0 & 13.4 & 38.2 & 13.9 \\
\hline 7.5 & 40.1 & 14.5 & 40.4 & 14.9 & 39.0 & 14.5 & 38.7 & 14.5 & 39.6 & 14.6 \\
\hline Mean & 40.0 & 14.4 & 40.0 & 14.7 & 37.7 & 13.7 & 36.8 & 13.6 & & \\
\hline CD at $1 \%$ & & $\mathrm{pH}$ & & $\mathrm{Cd}$ & & $\mathrm{pH} \times \mathrm{Cd}$ & & & & \\
\hline Biomass & & NS & & 1.57 & & NS & & & & \\
\hline Fruit weight & & NS & & NS & & NS & & & & \\
\hline
\end{tabular}

$$
3.000
$$

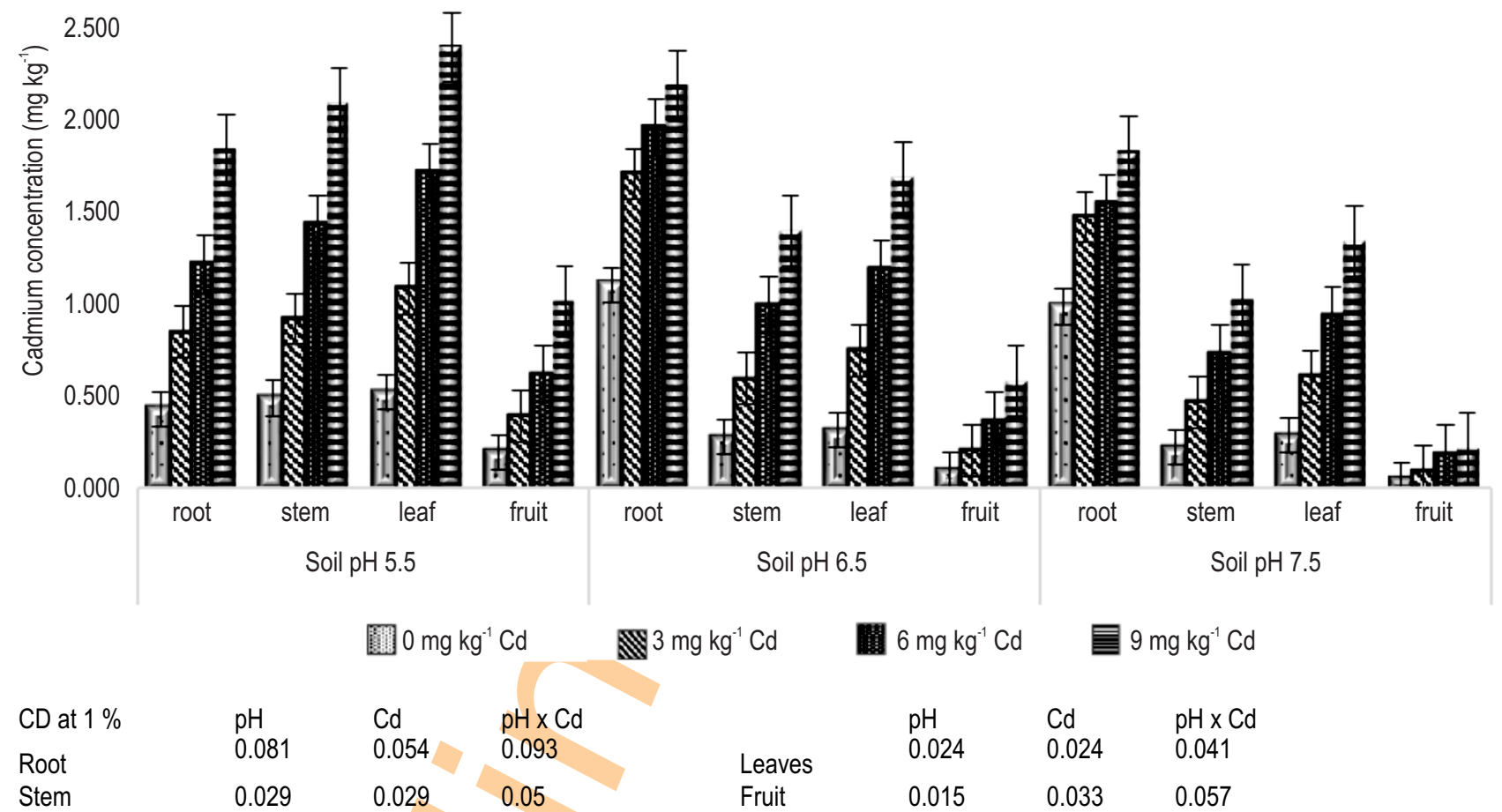

Fig. 2 : Cadmium concentration in different parts of okra plant under different doses of cadmium level and soil pH.

2007) even at $9 \mathrm{mg} \mathrm{kg}^{-1} \mathrm{Cd}$ when the soil was limed to slightly alkaline soil pH (7.5).

The soil pH had significant effect on the concentrations of $\mathrm{Cd}$ in different plant parts (Fig. 2). Decreased Cd concentrations at higher soil pH were conspicuous in all parts except roots. As application lime $\left(\mathrm{CaCO}_{3}\right)$ resulted in the higher soil $\mathrm{pH}$, the other factors might have changed as well. The rise in $\mathrm{pH}$ of soil solution releases free $\mathrm{Ca}^{+2}$ ions resulting into increased $\mathrm{Ca}^{+2}$ in soil solution, thereby, increasing its availability to plants. Since $\mathrm{Ca}^{2+}$ $\left(0.99 \mathrm{~A}^{0}\right)$ and $\mathrm{Cd}^{2+}\left(0.97 \mathrm{~A}^{0}\right)$ ions have similar ionic radii and are thought to be taken up by many plants in the same way. Increase in Ca might have outcompeted Cd for plant uptake. Ferreira et al. (2013) reported that $\mathrm{Ca}$ concentration in the soil solution leads to a drastic alleviation and even neutralization of $\mathrm{Cd}$ stress in several Fabaceae species.

Transfer factor is an indicator of metal accumulation from soil to different plant parts and was calculated as the ratio of concentrations of $\mathrm{Cd}$ in plant parts and soil (Table 2). 
Table 2 : Transfer factor of cadmium from soil to different parts of okra plant

\begin{tabular}{llllll}
\hline Soil pH & Cd $\left(\mathrm{mg} \mathrm{kg}^{-1}\right)$ & Root & Stem & Leaves & Fruit \\
\hline 5.5 & 0 & 0.18 & 0.203 & 0.223 & 0.081 \\
5.5 & 3 & 0.173 & 0.187 & 0.221 & 0.080 \\
5.5 & 6 & 0.164 & 0.193 & 0.232 & 0.083 \\
5.5 & 9 & 0.173 & 0.197 & 0.226 & 0.096 \\
6.5 & 0 & 0.459 & 0.114 & 0.130 & 0.040 \\
6.5 & 3 & 0.348 & 0.121 & 0.152 & 0.041 \\
6.5 & 6 & 0.265 & 0.134 & 0.160 & 0.049 \\
6.5 & 9 & 0.206 & 0.131 & 0.159 & 0.055 \\
7.5 & 0 & 0.409 & 0.091 & 0.118 & 0.018 \\
7.5 & 3 & 0.300 & 0.095 & 0.124 & 0.019 \\
7.5 & 6 & 0.209 & 0.099 & 0.126 & 0.025 \\
7.5 & 9 & 0.172 & 0.096 & 0.126 & 0.003 \\
CD $1 \%$ & $\mathrm{pH}$ & 0.017 & 0.008 & 0.009 & 0.004 \\
& $\mathrm{Cd}$ & 0.009 & 0.006 & 0.007 & 0.007 \\
\hline
\end{tabular}

Accumulation and distribution of metals in different plant parts are dependent on many factors like level of the metal in soil and air, plant species, soil pH, bioavailability, climatic condition, vegetation period and many other factors (Filipovic-Trajkovic et al., 2012). In the present study, all the factors remained same (assumption) except levels of $\mathrm{Cd}$ and soil $\mathrm{pH}$. At any given $\mathrm{pH}$ the transfer factors varied among different plant parts and were in the decreasing order of leaves $>$ stem $>$ root $>$ fruit at acidic $\mathrm{pH}$ (5.5) and root $>$ leaves $>$ stem $>$ fruit at higher $\mathrm{pH}$. At pH 5.5, most of the absorbed $\mathrm{Cd}$ by roots $(0.172)$ translocated to the shoots (leaves and stem 0.195 and 0.225 ). Whereas at higher $\mathrm{pH}$, transfer factor of $\mathrm{Cd}$ to root was significantly higher than stem, leaves, and fruits.

To understand the response pattern of okra plant, another indicator Translocation factors (TL) were calculated as the ratio between the $\mathrm{Cd}$ concentrations in two plant parts. TL for stem/root or leaves/stem did not vary in acidic soil condition ( $\mathrm{pH} \mathrm{5.5)} \mathrm{with}$ increasing $\mathrm{CdCl}_{2}$ application. This indicates the quantity of $\mathrm{Cd}$ absorbed at root is moved to leaves via xylem and accumulated. Uraguchi et al. (2009) suggested that the root-to-shoot Cd translocation via the xylem is the major and common physiological process determining the $\mathrm{Cd}$ accumulation level in shoots and grains of rice plants. At low $\mathrm{pH}$, higher $\mathrm{Cd}$ accumulation in presence of high $\mathrm{Cl}^{-}$ions was also been reported earlier (Hattori et al., 2005). Further the translocation factor fruit/leaves varied at $<1(0.37-0.42)$ indicating much lesser accumulation in fruits.

At slightly acidic (6.5) to slightly alkaline condition ( $\mathrm{pH} 7.5)$ the translocation factor stem/root decreased almost 5 folds over acidic soil $\mathrm{pH}$ (5.5) indicating that more than $50 \%$ of the accumulated $\mathrm{Cd}$ are retained in roots of okra. Probably plants are not able to metabolize or eliminate $\mathrm{Cd}$. Rather, they adopt the strategy of making complexes like Cd-Glutathione (GSH) and Cd-
Phytochelatins (PCs) to sequester $\mathrm{Cd}$ within vacuoles efficiently (DalCorso et al., 2008) and also not able to transport Cd over a long distance through xylem and phloem vessels (MendozaCózatl et al., 2008). Cadmium stress can be countered with "avoidance" when plants limit cadmium uptake, or by "tolerance" when plants endure high internal cadmium concentration. Avoidance involves reducing the concentration of metal entering the cell by extracellular precipitation, biosorption to cell walls, reduced uptake, or increased efflux. In another situation, heavy metals $(\mathrm{HM})$ are intracellularly chelated through the synthesis of amino acids, organic acids, GSH, or HM-binding ligands such as metallothioneins (MTs), phytochelatins (PCs), compartmentation within vacuoles, and upregulation of the antioxidant defense and glyoxalase systems to counter the deleterious effects caused by reactive oxygen species (ROS) and methylglyoxal (MG) (Hossain et al., 2012). This study corroborates that after Cd absorption in the root symplasm, further transport to the xylem is thought to be restricted by the production of phytochelatins and the subsequent sequestration of the $\mathrm{Cd}$-chelate complexes in root vacuoles (Lux et al., 2010) in soil limed to higher pH. In all probability, the mechanism of $\mathrm{Cd}$-sequestration within root vacuoles of okra was more functional at higher $\mathrm{pH}$ which is a favorable condition for okra and it grows best in slightly acidic to alkaline soil conditions. The sequestration mechanism was probably dysfunctional at low $\mathrm{pH}$ resulting into rather unrestricted movement to okra shoots. Another possible reason for low $\mathrm{Cd}$ translocation to shoots may have been the enhanced $\mathrm{Ca}$ accumulation in shoots. Calcium is also involved in the synthesis of glutathione, a precursor of phytochelatin. Phytochelatin inactivates $\mathrm{Cd}$ ions through chelation and prevent its entry into cytosol (López-Climentet al., 2014).

The net photosynthesis rate of okra was recorded maximum at 14.3 and $14.2 \mu \mathrm{mol} \mathrm{O}_{2} \mathrm{~m}^{-2} \mathrm{~s}^{-1}$ at both 30 and 60 days after sowing at slightly acidic soil $\mathrm{pH}(6.5)$ than any other soil $\mathrm{pH}$ 
Table 3: Translocation factors of cadmium among okra plant parts

\begin{tabular}{|c|c|c|c|c|c|c|}
\hline Soil pH & Cd levels & Stem/root & Leaves/stem & Fruit/root & Fruit/stem & Fruit/leaves \\
\hline 5.5 & 0 & 1.17 & 1.11 & 0.463 & 0.39 & 0.37 \\
\hline 5.5 & 3 & 1.08 & 1.18 & 0.452 & 0.42 & 0.36 \\
\hline 5.5 & 6 & 1.14 & 1.21 & 0.477 & 0.42 & 0.36 \\
\hline 5.5 & 9 & 1.17 & 1.14 & 0.580 & 0.50 & 0.42 \\
\hline 6.5 & 0 & 0.24 & 1.25 & 0.091 & 0.37 & 0.31 \\
\hline 6.5 & 3 & 0.36 & 1.26 & 0.122 & 0.34 & 0.27 \\
\hline 6.5 & 6 & 0.50 & 1.23 & 0.188 & 0.38 & 0.31 \\
\hline 6.5 & 9 & 0.65 & 1.22 & 0.275 & 0.42 & 0.35 \\
\hline 7.5 & 0 & 0.23 & 1.28 & 0.042 & 0.19 & 0.15 \\
\hline 7.5 & 3 & 0.32 & 1.33 & 0.065 & 0.21 & 0.15 \\
\hline 7.5 & 6 & 0.48 & 1.30 & 0.121 & 0.25 & 0.20 \\
\hline 7.5 & 9 & 0.56 & 1.31 & 0.121 & 0.21 & 0.37 \\
\hline \multirow[t]{3}{*}{ CD at $1 \%$} & $\mathrm{pH}$ & 0.097 & $0.13(\mathrm{P} 0.05)$ & 0.03 & 0.04 & 0.018 \\
\hline & $\mathrm{Cd}$ & 0.06 & NS & 0.04 & 0.02 & 0.018 \\
\hline & $\mathrm{pH} \times \mathrm{Cd}$ & 0.1 & NS & 0.07 & 0.042 & 0.031 \\
\hline
\end{tabular}

\footnotetext{
16
}

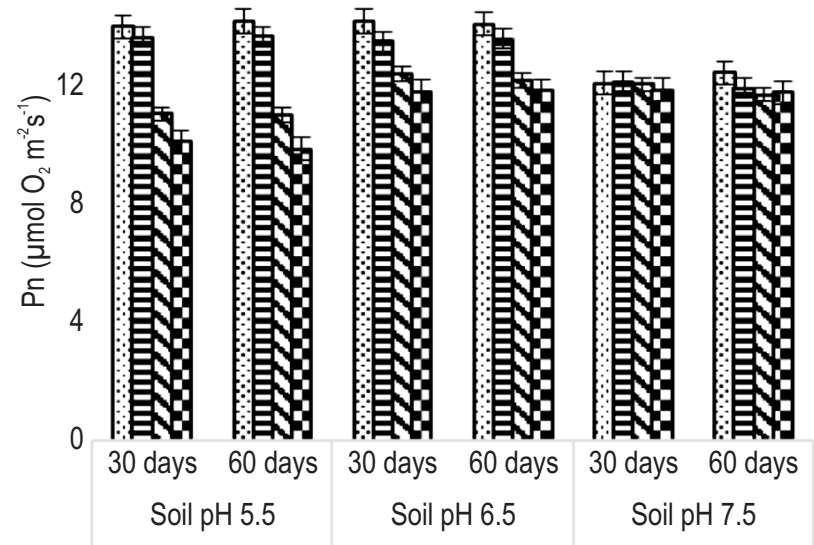

圈 $0 \mathrm{mg} \mathrm{kg}^{-1} \mathrm{Cd}$ 厈 $3 \mathrm{mg} \mathrm{kg}^{-1} \mathrm{Cd} \mathbf{\mathbf { N }} 6 \mathrm{mg} \mathrm{kg}^{-1} \mathrm{Cd} \mathbf{\mathbf { N }} 9 \mathrm{mg} \mathrm{kg}^{-1} \mathrm{Cd}$ $\mathrm{CD}$ at $1 \% \mathrm{pH} \mathrm{0.99;} \mathrm{Cd} 0.45 ; \mathrm{pH} \times \mathrm{Cd} 0.77$ (30 days) : $\mathrm{pH} 0.53 ; \mathrm{Cd} 0.51 ; \mathrm{pH} \times \mathrm{Cd} 8.78$ (60 days)

Fig. 3 : Effect of different level of cadmium concentration on photosynthetic rate of okra.

(Fig. 3). Probably the most favorable soil pH for okra among the three $\mathrm{pH}$ levels is 6.5. There is also decrease in net photosynthesis rate in okra with increase in dosage of $\mathrm{CdCl}_{2}$ at acidic (5.5) and slightly acidic soil pH (6.5). Many researchers have reported the disturbed oxidizing system of PS II as affected by $\mathrm{Cd}$ replacing the $\mathrm{Ca}^{2+}$ and $\mathrm{Mn}^{2+}$ ions in the PS II reaction centre; thereby inhibiting the reaction of PS II which leads to the uncoupling of the electron transport in the chlorophyll (Faller et al., 2005; Krantev et al., 2008). However, the rate of decline was

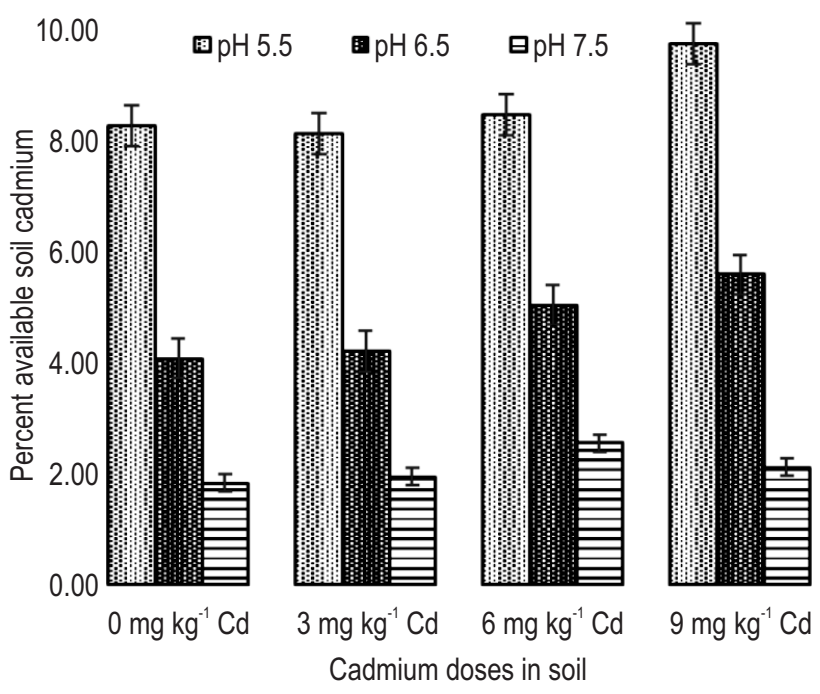

Fig. 4 : Percent available cadmium of total cadmium in soil at different soil $\mathrm{pH}$ and different doses of $\mathrm{Cd}$ application.

less at $\mathrm{pH} 6.5$ than 5.5. Further higher $\mathrm{pH}$ (7.5) had no impact on photosynthesis rate of higher $\mathrm{Cd}$ doses. The impact of $\mathrm{Cd}$ application was pronounced at 6 and $9 \mathrm{mg} \mathrm{kg}^{-1} \mathrm{CdCl}_{2}$ application. $\mathrm{Cd}$ toxicity can impair stomatal conductance, partly because $\mathrm{Ca}$ channels, which play a key role in controlling guard cell regulation, are permeable to $\mathrm{Cd}$. However, high tissue $\mathrm{Ca}$ concentrations can counteract $\mathrm{Cd}$-induced stomatal closure, which would otherwise lead to decreased $\mathrm{CO}_{2}$ fixation (PerfusBarbeoch et al., 2002). 
Soil properties and ionic composition of soil solutions regulate the dynamic equilibrium between metals in soil solution and soil solid phase and thus control the availability of metal to plant and its consequential uptake. The DTPA extractible soil cadmium, an indicator of phyto-availability of $\mathrm{Cd}$, were found to decrease with increase in soil $\mathrm{pH}$. Similar observation is also corroborated by other workers (Zeng et al., 2016). The soil pH is considered to be the most important factor controlling phytoavailability of certain metal contaminants, such as $\mathrm{Cd}, \mathrm{Pb}$ and $\mathrm{Cu}$. Increased sorption of metal ions with increasing soil pH might be due to increased negative surface charge of soils containing large quantities of iron and aluminium oxides. However, for metals that form oxyanions and metalloids such as As, increasing the $\mathrm{pH}$ decreases their sorption by soils. In this study, DTPA extractible $\mathrm{Cd}$ was about $10 \%$ of total soil $\mathrm{Cd}$ at low $\mathrm{pH}$ (5.5) which further reduced to less than $2 \%$ at higher soil pH (Fig. 4). Therefore, lower $\mathrm{Cd}$ concentration in okra plant parts at higher soil pH is attributed to the decreased availability of $\mathrm{Cd}$ in soil solution.

Cd toxicity was pronounced at low soil $\mathrm{pH}$ with decreased biomass yield and reduced photosynthetic activities. The impact was weakened with raised soil $\mathrm{pH}$ through liming. Cadmium accumulation was more in leaves at acidic soil pH. At higher soi $\mathrm{pH}$ (slightly acidic and alkaline), more $\mathrm{Cd}$ was retained in roots. Therefore, liming can be an effective ameliorative measure to reduce $\mathrm{Cd}$ toxicity in okra grown in $\mathrm{Cd}$ polluted acidic soils. Lowest accumulation of cadmium in okra fruits suggests it to be a potential vegetable crop for cadmium polluted soils.

\section{Acknowledgment}

We are thankful to the Director, ICAR - Indian Institute of Water Management, Bhubaneswar for providing infrastructural support.

\section{References}

Allen, S.E., H.M. Grimshaw and A.P. Rowland: Chemical Analysis. In Methods in Plant Ecology (Eds.: P.D. Moore and S.B. Chapman) Blackwell Scientific Publication, Oxford, London, pp. 285-344 (1986).

Balkhair, K.S. and M.A. Ashraf: Field accumulation risks of heavy metals in soil and vegetable crop irrigated with sewage water in western region of Saudi Arabia. Saudi J. Biol. Sci., 23, S32-S44 (2016).

Baruah, T.C. and H. P. Barthakur: A Text Book of Soil Analysis. UBS Publishers Ltd., New Delhi (1997).

Brown, J.R. and J.R. Cisco: An improved Woodruff buffer for estimation of lime requirement. Soil Sci. Soc. Am. J., 48, 587-591 (1984).

Chandran, S., V. Niranjana and Bennyjoseph: Accumulation of heavy metals in wastewater irrigated crops in Madurai, India. J. Environ. Res. Develop., 6, 432-438 (2012).

Chen, W., L. Li, A.C. Chang, L. Wu, S. Kwon and R. Bottoms: Cadmium uptake by lettuce in fields treated with cadmium-spiked phosphorus fertilizers. Commun. Soil. Sci. Plant Anal., 40, 11241137 (2009).

DalCorso, G., S. Farinati, S. Maistri and A. Furini: How plants cope with cadmium: Staking all on metabolism and gene expression. J.
Integr. Plant Biol., 50, 1268-1280 (2008).

Edgell, K.: USEPA Method Study 37-SW-846 Method 3050 Acid digestion of sediments, sludges and soils. EPA Contract No. 6803-3254 (1988).

Faller, P., K. Kienzler and A. Krieger-Liszkay: Mechanism of $\mathrm{Cd}^{2+}$ toxicity: $\mathrm{Cd}^{2+}$ inhibits photoactivation of Photosystem II by competitive binding to the essential $\mathrm{Ca}^{2+}$ site. Biochim. Biophys. Acta., 1706, 158-164 (2005).

Ferreira, P.A. A., G. Lopes, C. A. Bomfeti, S. M. de Oliveira Longatti, C. R. F. D. Soares, L. R.G. Guilherme and F.M. de Souza Moreira: Leguminous plants nodulated by selected strains of Cupriavidus necator grow in heavy metal contaminated soils amended with calcium silicate. World J. Microbiol. Biotechnol., 29, 2055-2066 (2013).

Filipovic-Trajkovic, R., S.Z. Ilic and L. Sunic: The potential of different plant species for heavy metals accumulation and distribution. J. FoodAgric. Environ., 10, 959-964 (2012).

Ghosh, A.K., M.A. Bhatt and H.P. Agrawal: Effect of long-term application of treated sewage water on heavy metal accumulation in vegetables grown in Northern India. Environ. Monit. Assess., 184, 1025-36 (2012).

Gu, J., L. Qi, W. Jiang and D. Liu: Cadmium accumulation and its effects on growth and gas exchange in for Populus cultivars. Act. Biol. Cracoviensia Series Bot., 2, 7-14 (2007).

Hattori, H., K. Kuniyasu, K. Chiba and M. Chino: Effect of chloride application and low soil $\mathrm{pH}$ on cadmium uptake from soil by plants. Soil Sci. Plant Nutr., 52, 89 -94 (2005)

Hossain, M.A., P. Piyatida, J.A.T. da Silva and M. Fujita: Molecular mechanism of heavy metal toxicity and tolerance in plants: Central role of glutathione in detoxification of reactive oxygen species and methylglyoxal and in heavy metal chelation. J. Bot., 2012, Article ID 872875, p. 37 (2012)

Indian Horticulture Database, National Horticulture, Board, Ministry of Agriculture, Government of India, p. 278 (2011).

Krantev, A., R. Yordanova, T. Janda, G. Szalai and L. Popova : Treatment with salicylic acid decreases the effect of cadmium on photosynthesis in maize plants. J. Plant Physiol., 165, 920-931(2008)

Lindsay, W.L. and W.A. Novell: Development of a DTPA soil test for zinc, iron, manganese and copper. Soil Sci. Soc. Am. J., 42, 421-428 (1978).

López-Climent, M. F., V. Arbona, R. M. Pérez-Clemente, S. I. Zandalinas and A. Gómez-Cadenas: Effect of cadmium and calcium treatments on phytochelatin and glutathione levels in citrus plants. Plant Biol., 16, 79-87 (2014).

Lux, A., M. Martinka, M. Vaculik and P. J. White: Root responses to cadmium in the rhizosphere: A review. J. Exp. Bot., 62, 21-37 (2010).

Mabberley, D.J.: The plant book: A portable dictionary of the vascular plants; utilizing Kubitzki's the families and genera of vascular plants (1990-), cronquist's an integrated system of classification of flowering plants (1981) and current botanical literature arranged largely on the principles of editions 1-6 (1896/97-1931) of Willis's A Dictionary of the Flowering Plants and Ferns, Cambridge University Press (1997).

Mendoza-Cózatl, D. G., E. Butko, F. Springer, J. W. Torpey, E.A. Komives, J. Kehr and J.I. Schroeder: Identification of high levels of phytochelatins, glutathione and cadmium in the phloem sap of Brassica napus. A role for thiol-peptides in the long-distance 
transport of cadmium and the effect of cadmium on iron translocation. Plant J., 54, 249-259 (2008).

Perfus-Barbeoch, L., N. Leonhardt, A. Vavasseur and C. Forestier: Heavy metal toxicity: Cadmium permeates through calcium channels and disturbs the plant water status. Plant J., 32, 539-548 (2002).

Pilipovic, A., N. P Nikolic, S. Orlovic, B. Krstic: Cadmium phytoextraction potential of poplar clones (Populus spp.). Zeitschrift fur Naturforschung, 60, 247-251 (2005)

Rezvani, M. and F. Zaefarian: Bioaccumulation and translocation factors of cadmium and lead in Aeluropus littoralis. Aust. J. Agric. Eng., 2, 114-119 (2011).

SAS Institute Inc.: SAS/STAT® 9.2 User's Guide. Cary, NC: SAS Institute Inc. (2008).

Singh, A., R.K. Sharma, M. Agarwal and F. Marshall: Health risk assessment of heavy metals via dietary intake of foodstuffs from the wastewater irrigated site of a dry tropical area of India. Food Chem. Toxicol., 48, 611-619 (2010).

Strauss, M. and U. J. Bluementhul: Human waste use in agriculture and aquaculture. IRCWD Report No 09/90, International Reference Centre for Waste Disposal (IRCWD), Ueberlandstrasse 133, CH8600 Duebendorf, Switzerland (1990).

Stritsis, C. and N. Claassen: Cadmium uptake kinetics and plants factors of shoot Cd concentration. Plant and Soil, 367, 591-603 (2013). doi:10.1007/s11104-012-1498-7

Usha Rani, K., K. L Sharma, K. Nagasri, D. Suma Chandrika, V. L. Savithri and M. Lal: Effect of long-term sewage water irrigation on micronutrient and heavy metal content in soil and plants under
Musi river basin in Hyderabad. J. Ind. Pollut. Cont., 30, 7-22 (2014).

Uraguchi, S., S. Mori, M. Kuramata, A. Kawasaki, T. Arao and S. Ishikawa: Root-to-shoot Cd translocation via the xylem is the major process determining shoot and grain cadmium accumulation in rice, J. Exp. Bot., 60, 2677-88 (2009).

Van Assche: A stepwise model to quantify the relative contribution of different environmental sources to human cadmium exposure. $8^{\text {th }}$ International Nickel-Cadmium Battery Conference, Prague, Chech Republic (1998)

Vig, K., M. Megharaj, N. Sethunathan and R. Naidu: Bioavailability and toxicity of cadmium to microorganisms and their activities in soil: A review. Adv. Environ. Res., 8, 121-135 (2003).

Vinu Radha, R., K. Kumutha and P. Marimuthu: Assessment of cadmium contamination of soils in sewage disposal areas of Coimbatore district, Tamil Nadu, India. Curr. World Environ., 9, 379-386 (2014).

WHO/FAO: Joint FAO/WHO Food Standards Programme, Codex Alimentarius Commission, $30^{\text {th }}$ Session. Report of the Thirty Eight Session of the Codex Committee on Food Hygiene. Houston, United States of America, p. 103 (2007).

World Health Organization: Guidelines for the safe use of wastewater, excreta and greywater in agriculture. Vol. 2, Wastewater use in agriculture. Geneva: World Health Organization (2006).

Zeng, W.A., F. Li , H. Zhou, X.L. Qin , Z.J. Zou , T. Tian , M. Zeng and B.H. Liao: Effect of calcium carbonate on cadmium and nutrients uptake in tobacco (Nicotiana tabacum L.) planted on contaminated soil. J. Environ. Biol., 37, 163-168 (2016). 